This item was submitted to Loughborough's Research Repository by the author.

Items in Figshare are protected by copyright, with all rights reserved, unless otherwise indicated.

\title{
Paradox and the negotiation of tensions in globally distributed work
}

PLEASE CITE THE PUBLISHED VERSION

https://doi.org/10.1177/0268396220936697

PUBLISHER

SAGE Publications

VERSION

AM (Accepted Manuscript)

\section{PUBLISHER STATEMENT}

This paper was accepted for publication in the journal Journal of Information Technology and the definitive published version is available at https://doi.org/10.1177/0268396220936697. Users who receive access to an article through a repository are reminded that the article is protected by copyright and reuse is restricted to non-commercial and no derivative uses. Users may also download and save a local copy of an article accessed in an institutional repository for the user's personal reference. For permission to reuse an article, please follow our Process for Requesting Permission.

\section{LICENCE}

All Rights Reserved

\section{REPOSITORY RECORD}

Brooks, Jade, M.N. Ravishankar, and Ilan Oshri. 2020. "Paradox and the Negotiation of Tensions in Globally Distributed Work". Loughborough University. https://hdl.handle.net/2134/12333074.v1. 


\title{
PARADOX AND THE NEGOTIATION OF TENSIONS IN GLOBALLY DISTRIBUTED WORK
}

\begin{abstract}
Tensions are a major source of communication problems, coordination issues and conflict in globally distributed work (GDW). In this paper we argue that extant literature falls short of addressing tensions in GDW at two levels. First, it fails to fully account for the intrinsic and entrenched nature of tensions in GDW, suggesting instead that they can be resolved or made to disappear. Second, it does not examine the key interactions amongst different kinds of tensions. Drawing on qualitative data from a distributed finance organization and applying concepts from paradox theory, we show how globally distributed units negotiate knowledge, power and identity tensions in collaborative work. The findings illuminate how a sequential enactment of both formal and informal solutions can better address tensions and generate collaborative opportunities in GDW. Building on the findings, we develop a phasal model of tension evolution and management in GDW which explains how tensions evolve from a phase of suppression through to a phase of attenuation. We demonstrate the interactions of knowledge-power-identity tensions against a background of defensive, interactive and collaborative behaviors, and suggest several practical implications for GDW practice.
\end{abstract}

\section{Keywords:}

Paradox, Globally Distributed Work, Case Study Research

\section{Introduction}

Organizations rely on globally distributed work (GDW) to take advantage of complementary objectives. In typical arrangements, highly skilled onshore teams focus on strategy and customer interactions, while offshore teams focus on repetitive back-office activities, reducing costs and improving efficiencies. Individually, each side can operate within the scope of their own tasks, priorities and values. However, when they are required to collaborate on distributed processes, tensions stemming from inherent contradictions in the working relationship cause strain and discomfort to both sides (Barney et al., 2014).

The extant literature recognizes three main sources of tensions in GDW: knowledge asymmetries (Vlaar et al., 2008; Hahl et al., 2016); power asymmetries (Levina and Vaast, 
2008; Ravishankar et al., 2013); and identity threats (Petriglieri 2011; Koppman et al., 2016) ${ }^{1}$. Collectively, these tensions can create communication problems (Levina and Vaast 2008; Hinds et al 2014), coordination issues (Oshri et al., 2008; Kotlarsky et al., 2014) and diminished opportunities for learning and innovation (Levina and Vaast, 2008; Tzabbar and Vestal, 2015). Tensions have also been found to reduce willingness to collaborate (Zimmerman and Ravishankar, 2014) and induce value-destroying conflict (Hinds and Mortensen, 2005; Ravishankar, 2015).

Much of the literature has focused on formal strategies for resolving and eliminating tensions. For instance, studies have found that codifying information helps reduce reliance on undocumented contextual knowledge (Leonardi and Bailey 2008; Oshri et al., 2008), and that brokering helps reduce knowledge silos (Leonardi and Bailey, 2008; 2013; Hahl et al., 2016). Research has also found that contracts play an important role in clearer distribution of power and responsibility (Di Tullio and Staples, 2013), while training programs, reassignment of tasks, and joint selection and promotion systems help readdress status imbalances (Levina and Vaast, 2008; Ravishankar et al., 2013). Similarly, cultural intermediaries such as 'inpatriates' who transcend subgroup differences help ease identity threats (Eisenberg and Mattarelli, 2016).

Despite the strengths of this body of research, two important issues are yet to be addressed. First, there is an implicit assumption in extant research that tensions between parties engaged in collaborative GDW can always be permanently resolved. However, this assumption fails to account for the intrinsic and entrenched nature of tensions in GDW, given the inherently contradictory aspects of many onshore-offshore relationships. In contradictory and inherently paradoxical settings, notwithstanding efforts targeting them, tensions are known to persist (Smith and Lewis, 2011). A key consequence of this preoccupation with permanent resolution is the limited focus on the process of generating meaningful collaborations within an entrenched system of onshore-offshore tensions. Second, prior research does not consider the interactions amongst different kinds of tensions and their implications for collaborative outcomes. Consequently, it remains unclear how successful collaborations are accomplished when multiple tensions are at play. In this paper, we respond to these two gaps in scholarship by addressing two specific research questions:

- RQ1: How are tensions in GDW turned into collaborative opportunities?

- RQ2: How do knowledge, power, and identity tensions relate to one another?

\footnotetext{
${ }^{1}$ We use the terms knowledge tensions, power tensions and identity tensions to refer to the corresponding tensions.
} 
Drawing on an in-depth qualitative case study of a distributed finance organization, we apply ideas from paradox theory (Lewis, 2000; Smith and Lewis, 2011) and offer an alternative approach to understanding tensions in GDW. The notion of paradox suggests that tensions are not permanently resolved in the traditional sense because leaning towards one polarity (such as cost reduction and efficiency) puts increasing pressure on the other polarity (such as quality and innovation) (Lewis, 2000; Smith et al., 2017). When applied to GDW settings, the paradox perspective helps us see that the successful implementation of collaborative GDW projects require managerial action and solutions different from the formal ones typically highlighted in the literature. Our findings suggest that defensive behaviors and attempts to force one side's preferred position may continue even after the implementation of formal solutions aimed at addressing tensions. While such behaviors strain interactions and result in a period of conflict, the findings show how subsequent informal managerial action can be central to improved mutual understanding and new collaborative ways of working.

Our study makes three contributions to research. First, we extend current debate in GDW, which mainly emphasizes the importance of formal solutions in managing tensions. Our findings point to the need for more sophisticated and nuanced solutions in the management of persistent and inter-related GDW tensions. Through the paradox lens, we demonstrate how a sequential enactment of both formal and informal solutions, rather than simple formal solutions (e.g. structural separation of the paradoxical units), can better address tensions and generate collaborative opportunities. Second, we develop a phasal model which explains how tensions evolve from a phase of suppression through to a phase of attenuation. It further describes and details the characteristics of specific behaviors associated with each phase. Third, we extend prior research by empirically illustrating the interactions of knowledge-power-identity tensions in GDW. In particular, we elucidate how these interactions unfold against a background of defensive and interactive-collaborative behaviors. These interactions suggest that structural changes in GDW can immediately amplify power and identity tensions. They also show how efforts to manage some tensions can impact a different type of tension in collaborative GDW. In the following sections, we review the literature on GDW with a specific focus on tensions and introduce paradox as an appropriate theoretical perspective. Next, we provide a detailed account of the methodology and case analysis. Finally, we discuss the paper's main theoretical and practical implications.

\section{Tensions in GDW}


Globally distributed work (GDW) involves the demarcation and division of work into dispersed task specific work units in order to enable innovative ideas (Levina and Vaast, 2008; Eisenberg and Mattarelli, 2016) as well as cost savings (Dibbern et al., 2008). The success of GDW mainly depends on the ability and willingness of onshore and offshore units to collaborate on distributed processes. It follows that variations in such ability and willingness create tensions between the two sides. The extant GDW literature finds there are three prominent sources of tensions at play: knowledge asymmetries, power asymmetries, and identity threats (Table 1). Knowledge asymmetries refer to the imbalance of knowledge and experience (Oshri et al., 2008; Vlaar et al., 2008) in performing specialized tasks (Tiwana and Keil, 2007; Leonardi and Bailey, 2013). Offshore units have been criticized for possessing only a limited knowledge of the onshore business and therefore contributing to poor organizational performance (Vlaar et al., 2008; Barney et al., 2014). For instance, Barney et al. (2014) found offshore Indian software engineers lacking in domain knowledge, leading to misunderstanding of requirements. On the other hand, onshore units have been criticized for information hiding (Connelly et al., 2012; Zimmerman and Ravishankar, 2014) and for not understanding offshore processes (Tiwana and Keil, 2007; Cha et al., 2008). Unmanaged knowledge asymmetries can hinder effective communication, reduce understanding (Levina and Vaast, 2008), limit positive knowledge spillover and reduce opportunities for joint problem solving (Jarvenpaa and Majchrzak, 2016). Firms invest in formal structures and systems to reduce knowledge tensions. Rules, standard operating procedures, codified directories and common lexicon are used to overcome gaps in knowledge (Oshri et al., 2008) and carefully designed structural arrangements help restrict the scope of collaborations, limit the need for knowledge sharing, and mitigate the opportunity for conflict (Oxley and Sampson, 2004).

Power asymmetries in GDW stem from imbalanced access to resources and decision makers, allowing some parts of the organization to enjoy a higher status than others (Levina and Vaast, 2008; Ravishankar et al., 2013; Hahl et al., 2016). In general, research has found that power resides in onshore units that control structural resources (Levina and Kane, 2009; Ravishankar et al., 2013). Levina and Kane (2009) found that onshore teams are well connected to senior decision makers and have better access to budgets, training and technology. Onshore units also assume a higher status on account of their perceived advanced language skills and qualifications (Hinds et al., 2014), engagement with higher-value tasks and superior domain expertise (Levina and Vaast, 2008). More recent research suggests that in knowledge intensive collaborations, it is difficult to determine 'who owns the code', decipher where decision- 
making power should reside and evaluate how rewards should be distributed (Chen et al., 2017; Parker et al., 2017). Organizations draft unambiguous contracts (Dibbern et al., 2008; Parker et al., 2017), legalize ownership of intellectual property and formalize the distribution of power via clearer documentation of responsibilities (Parker et al., 2017) to mitigate and manage the harmful impact of power asymmetries. Studies also indicate that service level agreements (SLAs) help formalize expectations and reduce power-related task conflicts (Goo et al., 2009; Deloitte, 2016).

Table 1: Review of sources of tensions in globally distributed work

\begin{tabular}{|c|c|c|c|c|}
\hline Source & Offshore Team & Onshore Team & $\begin{array}{l}\text { Avoid tensions } \\
\text { through: }\end{array}$ & Reference \\
\hline $\begin{array}{l}\text { Knowledge } \\
\text { asymmetries }\end{array}$ & $\begin{array}{l}\text { Possess } \\
\text { knowledge } \\
\text { specific to } \\
\text { migrated } \\
\text { activities; } \\
\text { have limited } \\
\text { business/domain } \\
\text { knowledge. }\end{array}$ & $\begin{array}{l}\text { Possess } \\
\text { business, } \\
\text { domain specific } \\
\text { knowledge; } \\
\text { have } \\
\text { less } \\
\text { understanding of } \\
\text { offshore } \\
\text { activities. }\end{array}$ & $\begin{array}{l}\text { - Standardization } \\
\text { and } \\
\text { decontextualizing } \\
\text { of information. } \\
\text { - Formal } \\
\text { communication } \\
\text { channels. }\end{array}$ & $\begin{array}{l}\text { Dibbern et } \\
\text { al., 2008; } \\
\text { Oshri et al., } \\
\text { 2008; Vlaar } \\
\text { et al., 2008; } \\
\text { Hahl et al., } \\
2016\end{array}$ \\
\hline $\begin{array}{l}\text { Power } \\
\text { asymmetries }\end{array}$ & $\begin{array}{l}\text { Less access to } \\
\text { resources and } \\
\text { limited decision- } \\
\text { making power. }\end{array}$ & $\begin{array}{l}\text { Excellent access } \\
\text { to resources; } \\
\text { possess } \\
\text { decision- } \\
\text { making powers. }\end{array}$ & $\begin{array}{l}\text { - Service level } \\
\text { agreements, } \\
\text { standard operating } \\
\text { procedures and } \\
\text { statement of work } \\
\text { documents that } \\
\text { outline } \\
\text { expectations, } \\
\text { assign decision- } \\
\text { making authority } \\
\text { and distribute } \\
\text { rewards and } \\
\text { penalties. } \\
\text { - Contract } \\
\text { management and } \\
\text { codifying } \\
\text { processes. }\end{array}$ & $\begin{array}{l}\text { Levina and } \\
\text { Vaast, 2008; } \\
\text { Ravishankar } \\
\text { et al., 2013; } \\
\text { Zimmerman } \\
\text { and } \\
\text { Ravishankar, } \\
\text { 2014; } \\
\text { Tzabbar and } \\
\text { Vestal, } 2015\end{array}$ \\
\hline $\begin{array}{l}\text { Identity } \\
\text { threats }\end{array}$ & $\begin{array}{l}\text { Believe they are } \\
\text { perceived as less } \\
\text { important by the } \\
\text { onshore side; feel } \\
\text { their } \\
\text { organizational } \\
\text { identity is being } \\
\text { threatened. }\end{array}$ & $\begin{array}{l}\text { Experience } \\
\text { threat of further } \\
\text { transfer of tasks } \\
\text { to the offshore } \\
\text { side; feel their } \\
\text { professional and } \\
\text { organizational }\end{array}$ & $\begin{array}{l}\text { - Cultural training. } \\
\text { - Cultural brokers } \\
\text { - Frames and } \\
\text { narratives to avoid } \\
\text { conflict. }\end{array}$ & $\begin{array}{l}\text { David et al., } \\
2008 ; \\
\text { Zimmerman } \\
\text { and } \\
\text { Ravishankar, } \\
2011 \text {; } \\
\text { Eisenberg } \\
\text { and }\end{array}$ \\
\hline
\end{tabular}




\begin{tabular}{|l|l|l|l|l|}
\hline & $\begin{array}{l}\text { identity is being } \\
\text { threatened. }\end{array}$ & & $\begin{array}{l}\text { Mattarelli, } \\
\text { 2016; } \\
\text { Koppman et } \\
\text { al., 2016 }\end{array}$ \\
\hline
\end{tabular}

Identity threats in the GDW context typically involve experiences that potentially violate an individual's or group's sense of professional self (Petriglieri, 2011; Koppman et al., 2016). Onshore identities are prone to threats as service offshoring matures, leading to migration of complex tasks (Zimmerman and Ravishankar, 2014; 2016) and increasing need for crosscultural interactions to accomplish the said tasks (Petriglieri, 2011). On the other side, research has shown how offshore units' sense of identity and organizational membership are threatened when they are treated as subordinates by their onshore counterparts (Leonardi and RodriguezLluesma, 2013; Koppman et al., 2016). In a study of German-Indian teams, Zimmerman and Ravishankar (2011) showed how offshore Indian engineers who considered themselves to be skilled professionals experienced significant identity threats when their onshore German colleagues assigned them repetitive and less interesting tasks.

Identity threats can give rise to a plethora of undesirable effects, including poor performance (Ravishankar, 2015), resistance to change (Zimmerman and Ravishankar, 2011), stigmatization (Major and O'Brien, 2005) and reluctance to share knowledge (Zimmerman and Ravishankar, 2011; Eisenberg and Mattarelli, 2016). Organizations have sought to resolve identity threats using cultural training (Newell et al., 2007; David et al., 2008) and intermediaries (or 'inpatriates'), who transcend cultural differences between subgroups and work to create a strong sense of identification with the larger organization (Eisenberg and Mattarelli, 2016). A small number of studies also show how more informal approaches such as framing narratives can be used strategically to resolve identity threats and temporarily reduce conflict in GDW (Petriglieri, 2011; Ravishankar, 2015).

\section{A paradox perspective}

Often described as 'two sides of the same coin', paradox is a condition where two individual elements are interrelated and necessary to each other's existence (Smith and Lewis, 2011), and yet seem to be opposing or contradictory (Poole and Van de Ven, 1989; Smith and Lewis, 2011). The tensions created by the pull of two paradoxical elements are not easily resolved since leaning towards one puts increasing pressure on the other (Lewis, 2000; Smith et al., 2017). In business and management research, the notion of paradox has been used to examine 
contradictory elements such as competition and cooperation in organizational alliances (Rai, 2016), exploitation of existing resources and exploration of new ideas in innovative projects (Andriopoulos and Lewis, 2009), and novelty and usefulness in creative endeavors (MironSpektor and Beenen, 2015). Within the IS literature, studies have considered paradoxical contradictions between control and autonomy in self-managing teams (Druskat and Wheeler, 2003), control and empowerment in hybrid teams (Cousins et al., 2007), flexibility and structure in client-supplier innovation projects (Kotlarsky et al., 2016), and trust and mistrust in distributed teams (Zolin et al., 2004). Paradox brings into sharp focus the role of behaviors in heightening or relieving tensions created by the opposing elements. Paradox posits that defensive behaviors such as avoiding differences or forcing one-sided solutions may only provide temporary relief (Smith and Lewis, 2011). In fact, they can create vicious reinforcing cycles that perpetuate and intensify tensions (Lewis, 2000; Smith and Lewis, 2011). For example, individuals may defensively retreat to their own divisions and stop engaging with partners, worsening the tensions in collaborative-competitive relationships (Jarzabkowski et al. 2013); offshore teams may defend contradictory elements in offshoring as 'cultural differences', further amplifying tensions (Ravishankar, 2015).

The literature suggests two broad formal strategies for managing paradoxes (Poole and Van de Ven, 1989; Lewis, 2000). The first, separation-based strategy, involves demarcating and honoring conflicting elements. For instance, distinctive formal structures can create much needed physical and temporal separation between tension-elevating elements (Bengtsson and Kock, 2000; Mayasandra et al., 2006; Stadtler and Wassenhove, 2016). Bengtsson and Kock's (2000) study of 'coopetition' illustrates the creation of departments that focus on either competitive or cooperative strategies. Further, information technologies make it possible to minimize communication and task interdependence between separated teams whilst at the same time connecting them and supporting task integration (Dubé and Robey, 2009). Other studies suggest 'time-bound' separations - teams focusing on one strategy for a period before returning to attend to the other (Poole and Van de Ven, 1989). Although separation strategies may avoid conflict and instability, they sometimes ignore the potential of blending for turning disagreements into value-creation (Stadtler and Wassenhove, 2016; Johansen, 2018). Overall, however, separation-based strategies dominate managerial efforts aimed at managing paradoxes

The second, integration-based strategy, is less common and involves purposefully juxtaposing contradictory elements (Lewis, 2000; Lewis and Smith, 2011), thus seemingly 
intensifying tensions. However, if managed effectively, such tensions can be turned into good collaborative outcomes. For instance, Dubé and Robey (2009) found how employing individuals with experience of handling ambiguous situations, maintaining shared calendars for transparency and establishing a common focus while acknowledging differences helped overcome structure-flexibility tensions. In well-managed integration scenarios, actors break out of vicious cycles and move away from defensive responses by acknowledging tensions and reframing them as necessary or accepting them as natural conditions of work. The process of recognizing and accepting inherent contradictions can provide actors with a sense of 'freedom' in "learning to live with" the opposing elements (Lewis, 2000: 764). They may embrace tensions, making small cognitive and behavioral adjustments to find benefits within the otherwise tense environment (Jarzabkowski et al., 2013; Jarzabkowski and Le, 2016). Integration-based strategies can encourage critical self-reflection, stimulate more ambivalent interpretations of surroundings (Lewis, 2000; Smith et al., 2017) and avoid oversimplification of problems (Plambeck and Weber, 2010).

In summary, our synthesis of the literature suggests a paradoxical mindset (i.e., a readiness to embrace inherent contradictions) can help organizations find more accommodating solutions (Smith 2014; Bengtsson et al., 2016), improve organizational learning (Lewis 2000; Sundaramurthy and Lewis, 2003), innovate more (Andriopoulos and Lewis, 2009), have higher problem solving capabilities and adapt better to change (Schuman et al., 2010), have successful inter-firm alliances and achieve overall superior performance (Rai, 2016). In terms of current research, we know a lot more about 'why' organizations strive for a paradoxical mind-set than 'how' it is achieved (Stadtler and Wassenhove, 2016). In the specific context of GDW, there is limited understanding of how tensions can be turned into collaborative ways of working. Further, there is scarce research on the implications of interactions amongst different tensions for collaborative outcomes. In the following sections, we present the case of a distributed finance function, where work has been demarcated and distributed between two sides - onshore business units and an offshore shared service center. Using this case, we explain how the two sides negotiate tensions and explicate the role of a sequential enactment of both formal (integration-based) and informal managerial solutions in generating collaborative opportunities.

\section{Design and methods}




\section{Research approach}

We wanted our research approach to allow us to explore the potentially complex challenges onshore-offshore unit members face as they collaborate. In line with past research, we adopted the qualitative case study method (Walsham, 2006) which generates rich data and helps advance understanding of under-researched phenomenon (Eisenhardt, 1989; Kotlarsky et al., 2014). We drew predominantly on interview data from both onshore and offshore units to gain an in-depth understanding of the structural, as well as the social context of collaborative GDW. The findings report data that emerged organically from our interpretivist approach to data analysis.

\section{Research setting}

Our research is set in the finance function of a large global logistics firm made up of four business divisions. Our research focuses on the paradox emerging from the migration of financial tasks from several onshore country level business units (BUs) within the firm's largest business division to an offshore shared service unit (SSU). Our empirical material provides retrospective accounts, triangulated with several data sources, to capture tensions across significant changes in organizational structure (Figure 1). Throughout the paper we refer to employees working in the SSU as 'SSU members' and employees working in BUs as 'BU members'.

Figure 1: Finance function organizational structure

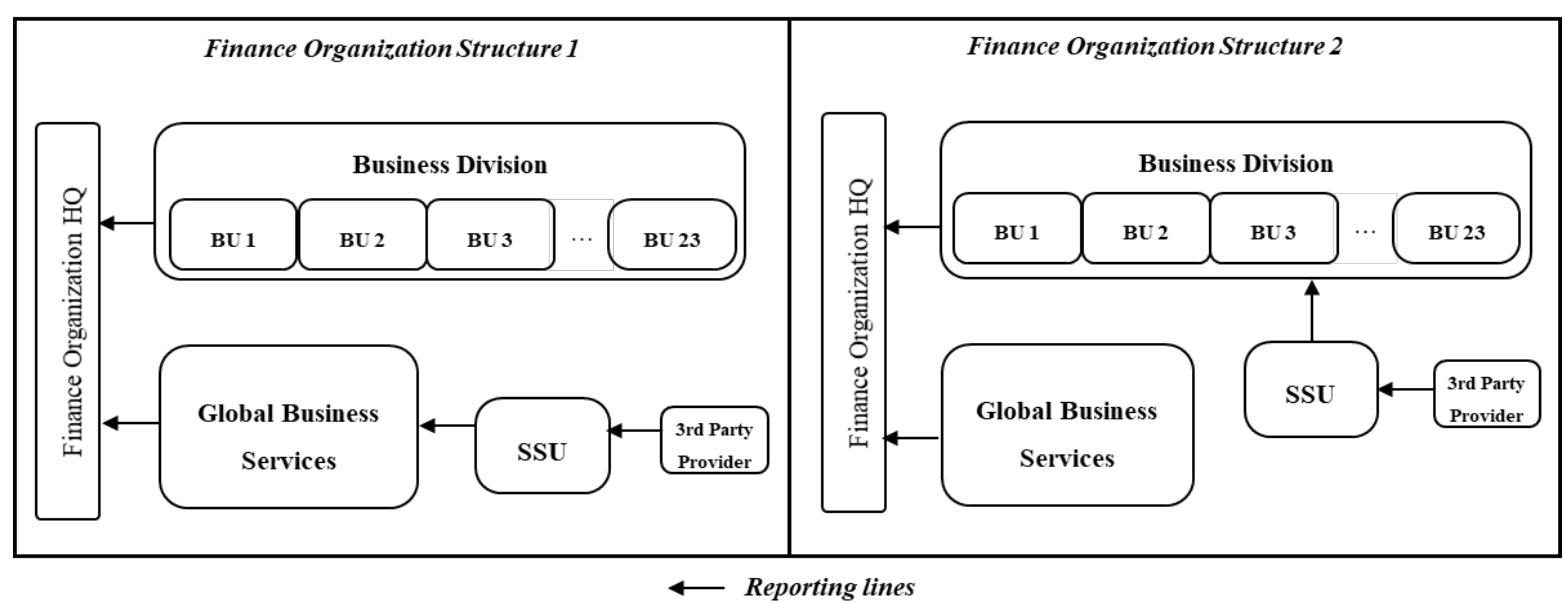

Finance Organization Structure 1: Centralization of financial operations into GBS 
A centralization strategy, which began in 2008, aimed to consolidate resources from across the multiple country level business units (BUs). Tasks were transferred out of the BUs into a dedicated financial shared services unit (SSU), which sat within a wider corporate center called Global Business Services (GBS). In addition to finance, GBS provided a range of support services to the BUs including procurement, legal, HR and IT support. The idea of centralizing finance was to help BUs improve financial reporting, better manage financial risk and improve customer focused activities. For instance, it was anticipated that moving a range of activities into the SSU would give BU members more time to visit customers, better understand their financial and shipment needs, offer more tailored customer service and increase sales by generating larger shipping orders. The SSU focused on standardizing and delivering a range of financial operations to the BUs such as the purchasing and paying for goods and services. The BUs paid for the SSU's services, which were governed via SLAs and performance was measured through key performance indicators (KPIs). During this period, BU members became increasingly dissatisfied with the service provided by the SSU. BU members were focused on being more responsive to customer queries and offering flexibility through shipment discounts and differentiated payment plans. SSU members, on the other hand, were focused on reducing the cost of finance and standardizing processes to gain efficiencies. In 2011, to achieve further cost savings, some transactional activities related to the invoicing provision were outsourced to a third-party provider. BU members saw this outsourcing arrangement as being at odds with their priorities and this view led to several BU-SSU disagreements. SSU members were also tasked with the long-term improvement of financial processes through standardization, integration of existing information systems and the implementation of new IT tools across multiple BUs. However, the BUs did not always have the funds to support these SSU objectives. Projects deemed to not have an immediate impact on BUs were often rejected by BU members who were more focused on their annual sales targets.

\section{Finance Organization Structure 2: SSU integration into Business Division}

In late 2014 the SSU's reporting lines were changed and it was integrated into the business division. The SSU did not physically change location, and tasks remained centralized, but SSU members now reported to the business division rather than to GBS. As the SSU became integrated into the business division, BU and SSU members were expected to collaborate more closely to perform and improve distributed processes. Our data describes the tensions between the BUs (onshore units) and the SSU (offshore unit), given their conflicting objectives (see 
Table 2), and explains the process of accommodating contradictory needs and creating collaborative opportunities.

Table 2: Conflicting responsibilities and objectives of SSU and BUs

\begin{tabular}{|c|l|l|}
\hline \multirow{5}{*}{ Objectives } & $\begin{array}{l}\text { Shared Service Unit (SSU) } \\
\text { Reduce the cost of financial } \\
\text { operations } \\
\text { Long-term improvement of } \\
\text { finance operations }\end{array}$ & $\begin{array}{l}\text { Business Units (BUs) } \\
\text { Improve financial position and customer } \\
\text { service }\end{array}$ \\
\hline $\begin{array}{l}\text { Tasks } \\
\text {-Delivery of financial } \\
\text { operations: purchase-to- } \\
\text { pay, record-to-report, } \\
\text { order-to-cash } \\
\text {-Standardize processes } \\
\text {-Integrate and standardize } \\
\text { information systems and } \\
\text { information technology } \\
\text { - Manage third-party } \\
\text { provider }\end{array}$ & $\begin{array}{l}\text { - } \\
\text { - Support regional and global finance } \\
\text { organizations } \\
\text {-Improve customer experience of financial } \\
\text { processes } \\
\text {-Improve the financial position of BU: projects } \\
\text { to speed up processing of invoices } \\
\text {-Support sales team to increase revenue: e.g. } \\
\text { work out discounts for customers to } \\
\text { encourage them to commit to larger shipments } \\
\text { or move from other logistics providers }\end{array}$ \\
\hline
\end{tabular}

\section{Data sources}

Data was collected in three rounds (see Table 3) in 2015-2016, mainly through in-depth interviews. Interviews focused on capturing retrospective accounts of the challenges participants faced as work was migrated into the SSU (focusing on 2008-2015), as well as accounts of the tensions participants faced as the finance function matured and transformed (2014-2016). The first round of interviews was conducted with SSU members at the offshore SSU head office in March 2015. With the help of an SSU manager, we selected participants from a range of management positions. (see Appendix for a complete list of positions and participant codes). The interviews were semi-structured and focused on 'change' and 'challenges' participants faced in their work. They were asked to elaborate and give examples of 'how' and 'why' they thought situations or events occurred. The intention was to let interesting themes emerge from this first round of data collection, whilst developing a good understanding of the organizational structure and its evolution, and the distribution of work and challenges of GDW. The second round of interviews in January 2016 also took place at 11 
the SSU head office. Interviewees included managers from the SSU and the firm's finance organization (FO) headquarters. The third round of interviews was conducted in June 2016 with BU participants from four different onshore countries.

Table 3: Rounds of data collection and nature of data collected

\begin{tabular}{|c|c|c|c|}
\hline Round & Interviewees & Interviews & Focus \\
\hline $\begin{array}{l}\text { 1: March } \\
2015\end{array}$ & $\begin{array}{c}\text { SSU } \\
\text { members }\end{array}$ & 9 & $\begin{array}{c}\text { To understand the global } \\
\text { organization of functions, } \\
\text { changes in the role of the SSU } \\
\text { and the corresponding } \\
\text { challenges. }\end{array}$ \\
\hline $\begin{array}{l}\text { 2: January } \\
2016\end{array}$ & $\begin{array}{l}\text { SSU and } \\
\text { finance } \\
\text { organization } \\
(\mathrm{FO}) \\
\text { headquarters' } \\
\text { members }\end{array}$ & 8 & $\begin{array}{l}\text { To understand tensions the } \\
\text { SSU members face in their } \\
\text { own work and in collaborative } \\
\text { projects. } \\
\text { To understand how SSU } \\
\text { members cope with tensions. }\end{array}$ \\
\hline $\begin{array}{l}\text { 3: June } \\
2016\end{array}$ & BU members & 9 & $\begin{array}{l}\text { To understand how BU } \\
\text { members experience and cope } \\
\text { with tensions in their own } \\
\text { work and in collaborative } \\
\text { projects. }\end{array}$ \\
\hline
\end{tabular}

The interviews lasted between 60 and 140 minutes, averaging 77 minutes and amounting to about 33 hours of interview data. All but three (teleconference) interviews were conducted face-to-face. We collected several other documents, including annual reports, internal communications, performance dashboards, employee opinion surveys and employee development initiatives. These documents helped understand the chronology of structural and organizational changes and offered additional insights into the behaviors of onshore-offshore members. We also spent time in the offices, spoke informally with several participants, took photographs of the working environment and produced field notes.

\section{Data analysis}

We took the opportunity to organize and analyze data at each round of data collection. First, we transcribed all interviews from round one, studied the data, and made extensive notes to identify emerging themes of each interview individually. Second, we combined the interview data with documentation and field notes. This helped us to map the organizational structure, reporting lines, workflow and responsibilities, objectives and performance metrics. Third, we 
set about identifying common themes across the complete round one dataset. To this end, we wrote short guiding narratives and constructed a table of themes. The presence of opposing objectives, the underlying power and knowledge asymmetries, and accounts of conflict between onshore (BUs) and offshore (SSU) units emerged organically from this round of interview data. We repeated this process for the second and third rounds of data collection. Data from the second round revealed in greater depth the conflicting objectives between the SSU and BUs and the apparent threats to participants' sense of professional self. FO informants discussed the application of formal tools and ICT to resolve issues, and the process of integrating the SSU into the business division. Data from the third round, consisting of BU interviews, also referred to different work, objectives, and highlighted the differences in the perceived value of work performed onshore - in the BUs, and offshore - in the SSU. At the completion of three rounds of interviews, we made extensive notes and created a thematic table of onshore-offshore conflicts and tensions (e.g., Corley and Gioia, 2004) and their ongoing management by the FO headquarters. We then went back to the literature and iterated between theoretical explanations and the data until we were confident that our interpretation reached a reasonable level of theory-data alignment.

\section{Case Analysis}

Table 4 juxtaposes the perceptions of members from four onshore BUs with those from the offshore SSU to illuminate the specific paradoxical tensions in the relationship. In the analysis below, we show how members moved from defensive behaviors, which intensified tensions, to collaborative behaviors which attenuated them. We follow the analysis with a detailed discussion section.

\section{Tensions and defensive behaviors}

As summarized in Table 4, contrasting objectives, differing levels of knowledge and access to key decision makers, and issues of identity created tensions between the SSU and the BUs. SSU members noted that they struggled to coordinate and control information because of the BUs' reluctance to share business knowledge. This restricted access meant that the SSU was not able to fully understand the BUs' requirements. SSU members also explained that they did know enough about the activities performed by the third-party provider, which further limited their ability to support the BUs. When explaining their weak knowledge position, SSU 
members noted that they were seen as a 'cost center' (i.e., the SSU did not directly generate revenue or make a profit and was instead perceived to cost the firm money). They reported that their position within the GBS, which was widely seen as a support service, had created a kind of status asymmetry between BU and SSU members. SSU members said that because they were support services, they were perceived as less capable, of less value, and as having different objectives to their BU counterparts. SSU members suggested they received limited financial investment and were unable to allocate resources needed to fully understand the activities performed in the BU, or to manage the third-party provider. In addition, despite being tasked with 'process improvement', they did not have the authority to implement new IT tools. Both BU and SSU members acknowledged the tensions as they transitioned towards a more centralized structure.

The business was always run in a very entrepreneurial way. The BUs were very autonomous. Then suddenly you have this central support unit (GBS) that says the BU are going to do it totally differently. (P1.1)

Several members referred to the disparity between BU and SSU decision-making power. While the SSU was given the responsibility to centralize and improve financial processes, senior managers in the SSU suggested that they did not have the "stick" or "the backing" from the finance organization (FO) headquarters to force BU members to accept process changes and new IT tools. They highlighted problems of knowledge and control, referring to the relationship as "artificial” (P2.1), with "virtual" (P1.2) and "psychological barriers" (P2.3; P2.7). They also felt they were treated like "suppliers" (P2.4) despite being internal to the firm. A senior SSU manager recalled a humiliating experience where the $\mathrm{BU}$ had dismissed plans to develop a financial process and suggested that they "needed to have somebody from the business division looking into it" (P2.4).

From the BUs' perspective, they were legally accountable to external auditors for financial documents produced by SSU members. They were also accountable to the business division for the quality of financial reporting, and to their customers for service quality. BU members felt this accountability was at odds with handing over control of related activities to the SSU. They did not have enough understanding of the SSU's activities to be able to generate the necessary reports or rectify mistakes. BU members also felt that the SSU's emphasis on IT standardization was in sharp contrast to the BUs' focus on flexibility. For instance, a BU member explained that their team's daily plan, which they referred to as a "living thing", was devised on a whiteboard and adapted throughout the day. Others noted that they frequently had 
to respond to urgent calls from customers and requests for information from senior managers. BU members saw the SSU as a "middleman" between themselves and the third-party provider who processed invoices. They felt this arrangement made accessing information and responding to customers more complex and time consuming. In addition, they questioned the SSU's ability to control and manage information and to improve financial processes. They highlighted the strategic importance of their own work and saw the SSU as the "poorer cousin... who got the bad stuff' (P3.5). On the other hand, SSU members felt unhappy at being perceived as merely a "cost saving entity" (P2.4) created to perform "transactional", "repetitive" and "back-office" work. They argued that such a view was not a true reflection of their ability to perform and improve processes. Many of them held master's degrees and formal accounting qualifications and argued that their low status in the relationship was unjustified. 
Table 4. Paradoxical tensions in GDW

\begin{tabular}{|c|c|c|c|c|c|}
\hline \multicolumn{2}{|c|}{ Source of tensions } & $\begin{array}{c}\text { SSU's perceived } \\
\text { tensions }\end{array}$ & SSU supporting data & $\begin{array}{l}\text { BUs' perceived } \\
\text { tensions }\end{array}$ & BU supporting data \\
\hline Knowledge & $\begin{array}{l}\text { Asymmetries in } \\
\text { process, domain } \\
\text { and business } \\
\text { knowledge }\end{array}$ & $\begin{array}{l}\text { Need to coordinate } \\
\text { activities but have } \\
\text { limited understanding } \\
\text { of customer business } \\
\text { and third-party } \\
\text { provider activities }\end{array}$ & 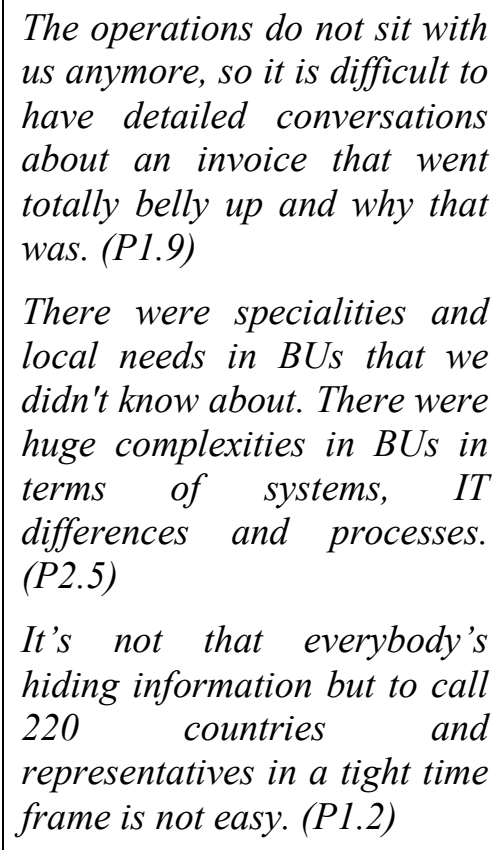 & $\begin{array}{l}\text { Have a detailed } \\
\text { understanding of own } \\
\text { business and end } \\
\text { customer needs but have } \\
\text { limited understanding of } \\
\text { wider processes. } \\
\text { Need to access } \\
\text { information on an } \\
\text { informal basis but are } \\
\text { reliant on formal } \\
\text { systems to improve } \\
\text { processes and increase } \\
\text { objectivity. }\end{array}$ & $\begin{array}{l}\text { When they (the customer) have an } \\
\text { information need it's always } \\
\text { urgent. (P3.9) } \\
\text { There's a disconnect. First, there's } \\
\text { a large gap between the SSU and } \\
\text { the customer. Second, they don't } \\
\text { just have one BU to manage. When } \\
\text { it was in-house, we were in control. } \\
\text { Now we are one of many the SSU } \\
\text { serve. (P.2.3) }\end{array}$ \\
\hline Power & $\begin{array}{l}\text { Asymmetries in } \\
\text { authority and } \\
\text { status }\end{array}$ & $\begin{array}{l}\text { Have limited access to } \\
\text { decision makers and } \\
\text { resources. Seen as a } \\
\text { cost-center. } \\
\text { Need to reduce costs } \\
\text { and produce } \\
\text { efficiencies but do not } \\
\text { have the authority or }\end{array}$ & $\begin{array}{l}\text { BUs wouldn't follow the } \\
\text { standard processes. They had } \\
\text { their own rules, their own } \\
\text { ideas, and were continuously } \\
\text { questioning us. They agree in } \\
\text { principle but say "it's not } \\
\text { possible for us" because of } \\
\text { whatever reason. (P1.6). }\end{array}$ & $\begin{array}{l}\text { Need to ensure the } \\
\text { quality of outcomes but } \\
\text { are expected to hand } \\
\text { over control of } \\
\text { processes. }\end{array}$ & $\begin{array}{l}\text { The decision power should always } \\
\text { lie with us in the BU. Transactional } \\
\text { work or data gathering can be with } \\
\text { them. (P3.9) } \\
\text { Control should sit with the person } \\
\text { responsible for the end impact. Our } \\
\text { CFO is responsible for his Profit } \\
\text { and Loss (and not the SSU). (P3.3) }\end{array}$ \\
\hline
\end{tabular}




\begin{tabular}{|c|c|c|c|c|c|}
\hline & & $\begin{array}{l}\text { the financial resources } \\
\text { to make changes. }\end{array}$ & $\begin{array}{l}\text { If a BU CFO said 'no I don't } \\
\text { see that happening' then it } \\
\text { didn't happen. We are a just a } \\
\text { cost-centre. (P1.2) } \\
\text { If we wanted to implement } \\
\text { something it was seen as a } \\
\text { huge one-off cost to the BUs. } \\
\text { They always said that they } \\
\text { only want to do projects that } \\
\text { pay back in two years or less. } \\
\text { There's not much we can do } \\
\text { then. (P1.1) }\end{array}$ & & \\
\hline Identity & $\begin{array}{l}\text { Threats to sense } \\
\text { of belonging }\end{array}$ & $\begin{array}{l}\text { Identify strongly with } \\
\text { the organization but } \\
\text { feel that they (SSU) } \\
\text { are treated like } \\
\text { external suppliers. } \\
\text { Need to collaborate } \\
\text { with BUs. But they } \\
\text { (SSU) are focused } \\
\text { solely on broad } \\
\text { organizational } \\
\text { objectives, which the } \\
\text { BUs find hard to relate } \\
\text { to. }\end{array}$ & $\begin{array}{l}\text { Us and them dynamic. (P2.6) } \\
\text { The BUs were autonomous. As } \\
\text { they were making profits, they } \\
\text { could do what they } \\
\text { wanted...they didn't } \\
\text { appreciate us. (P1.1) }\end{array}$ & $\begin{array}{l}\text { Acknowledge the SSU } \\
\text { but feel that external } \\
\text { units should not tell the } \\
\text { BUs what to do. } \\
\text { Need to collaborate with } \\
\text { the SSU, but struggle to } \\
\text { accept the SSU as a } \\
\text { same-status partner. }\end{array}$ & $\begin{array}{l}\text { The SSU was the poorer cousin who } \\
\text { got the bad stuff. (P3.5) } \\
\text { You (have to) end up with a } \\
\text { supplier-vendor relationship. } \\
\text { (P1.5) } \\
\text { The SSU is seen more as a cost } \\
\text { driving entity and the value driving } \\
\text { entity, the business, is separate. By } \\
\text { definition you are classifying a } \\
\text { group of people as a cost. (P2.4) }\end{array}$ \\
\hline
\end{tabular}




\section{Defensive behaviors}

SSU members claimed that the BUs actively resisted their (SSU's) efforts to standardize IT processes. BU members explained their resistance in terms of the rigidity the SSU initiatives could impose on the BUs' everyday work and on the BUs' freedom to make local adaptations. SSU members explained that BUs invoked the contractual nature of their relationship with the SSU to reject initiatives which aimed at further standardizing financial processes. These projects tended to be rejected because of the perceived cost.

The first question was always "What is it going to cost and what is going to be the impact on my SLA? They were saying 'I only want to do projects that pay back in two years or faster'. There's not much you can do... it just doesn't work. (P1.1)

Some SSU members explained that BU resistance was often supported by the business division, which did not enforce centralized process changes.

In the past if we challenged a process, we had nobody we could go to. If the BU didn't want to change, then they didn't change. The business division did not support our projects. We were there to deliver a service and that service could only be what the local $B U$ 'needed'. We've never had that backing. (P2.1)

To access information quickly, BUs often avoided standardized formal processes and contacted the third-party provider directly. Although this meant that issues were resolved locally, deeper and more fundamental issues with the process were not flagged or fixed.

I jump the gun and go to the [provider] to get a quick answer so I can quickly feedback to my manager. When it's to do with you, you're willing to jump any hoops to quickly resolve your issue. (P3.5)

From the SSU's perspective, these BU behaviors restricted their ability to perform their own roles effectively. One SSU member explained:

We were under continuous pressure to drive costs down. At the same time BUs were not allowing us to change and to optimise the process which would allow us to decrease costs! It's an interesting 'spagaat' [translation: splits] - cost reductions on one side and on the other side not being allowed to change the process. (P1.9)

The SSU responded by trying to limit communication exchanges between the BUs and the thirdparty provider. For instance, SSU members improved formal documentation to reduce the need for direct communication. They kept 'log books' to record all mistakes, process delays and complaints from BU members. SSU members also tried to force BUs to use formal protocol and 18 
communication channels by boycotting deviations and not completing work that did not align with the standard format.

Someone will phone up or send an email saying 'can you add this' and we say 'no you're not going to do that. You are going to send the form'. Often, we have implemented an IT tool they need and we make it stricter - and god that's something we want. We want to improve the controls. (P1.5)

The SSU also focused on the formal terms of their contracts with BUs in order to emphasize the obligations of all parties. SSU members invoked SLAs and statement of work documents, to reiterate the specific roles and objectives of the BUs, the third-party provider and the SSU. However, both BU and SSU members referred to SLAs (and the focus on contractual obligations) as one of the biggest collaborative challenges. BU members pointed out that SLAs codified the misaligned objectives between themselves and the SSU - cost reduction for the SSU and service quality for the BUs. They noted that the SSU, BUs and the third-party provider were rewarded through financial bonuses for meeting conflicting objectives. The SSU's bonuses were linked to cost savings and efficiencies, the BUs' to improving financial outcomes for the unit, and the thirdparty provider's bonuses were based on the number of invoices processed. They used the terms set out in the SLAs to defend their own objectives and bonuses. BUs showed their discontent with the SSU's inflexibility by issuing 'red SLAs' to signal that obligations had not been met. SSU members countered with 'blue SLAs' to justify their own actions, noting that the BUs had not provided the information needed for the SSU to fulfill its obligations. BU members felt that the SSU had developed a "fighter's mentality" (P2.6) and that the two sides became stuck in blaming contests and "stalemate" conversations about SLAs. At the same time, some BU members admitted that they found it challenging to hand over control of tasks they had earlier performed themselves.

Table 5: Defensive behaviors and impact on tensions

SSU defensive behaviors
BU defensive behaviors
Tensions 


\begin{tabular}{|c|c|c|}
\hline $\begin{array}{l}\text { Emphasized the separation of } \\
\text { responsibilities }\end{array}$ & $\begin{array}{l}\text { Worked around formal } \\
\text { channels to access } \\
\text { information }\end{array}$ & Amplified \\
\hline Enforced IT standardization & Resisted IT standardization & $\begin{array}{l}\text { Tensions made more } \\
\text { severe as both sides }\end{array}$ \\
\hline $\begin{array}{l}\text { Focused rigidly on contracts } \\
\text { and SLAs }\end{array}$ & $\begin{array}{l}\text { Monitored and escalated even } \\
\text { extremely minor violations of } \\
\text { contractual obligations }\end{array}$ & reach a "stalemate" \\
\hline
\end{tabular}

\section{Negotiating tensions}

In order to better align SSU's service provision with the needs of the BUs, the finance organization (FO) headquarters altered the organizational structure (Figure 1: Finance Organization Structure 2). The SSU was structurally removed from GBS and integrated into the business division. Beyond the structural change, there was a conscious effort to break "psychological barriers" and integrate the SSU into the division. Senior managers overseeing the transition made it clear that they did not want the structural change to be seen as a "hostile takeover" of the SSU by the division, but only as a means for the BUs and the SSU to "come together". They actively emphasized "togetherness" in their communications and referred to "putting pieces of the puzzle back together" and "working as one" (P2.6; P2.1; P2.5). The business division held a "welcome" event as a starting point for their new unity. One BU member said:

We held a small celebration with them (the SSU). You feel that people are more engaged to deliver the best they can, not just because we gave them a glass of prosecco and a couple of candies, but because we tell them: "Look, what you guys are doing is really important". We show them the value in what they're doing, and they see their full contribution to the network. Through the network you're part of the family. (P.3.9)

\section{Interactive behaviors}

The structural integration resulted in BU and SSU members being involved in more joint management meetings, joint service performance reviews (SPRs), and collaborative improvement projects. BU and SSU members reported that working together in this way was often more difficult than working independently. They found these meetings involved "uncomfortable" and "frank discussions". BUs also introduced a service 'health check' which rated service provision on a traffic light system (green - good, red - bad, and amber - requires improvement). Unlike formal 
performance indicators and SLAs these health checks focused on more informal measures such as sentiment and feelings.

Health checks gives a sense of how BU members are feeling about performance. For example, in November the UK BU felt there was just too much change. So it's not based on any poor performance - they just found the new IT tools overwhelming. The UK BU is big, so if there are new tools then a lot of people have to be trained... Norway was red but now it has gone to amber. They were unhappy about duplicate entries coming from a new tool. That is now gone but they kept it amber just for monitoring. They had no issues but just didn't feel confident about it. (P2.1)

Some results were disputed, leading to heated discussions. A BU member described a difficult exchange with the SSU:

With this new focus on quality, and them being in the business division the standard wasn't okay anymore. We needed big improvements, so we introduced a traffic light system for reporting. I can tell that it's been contentious. It's important to the SSU and we suddenly made them red when it had always been green. I could really sense some negative emotion about that. The service hadn't got worse it's just that we hadn't set the target high enough before. At the end of a call with them they said: "Is it green as usual?" and we said, "No. It's red". It was the wrong way to do it, but we have to work together and clean it up. (P3.3)

However, BU and SSU members noted that while meetings led to uncomfortable discussions and blame passing, they also provided opportunities to better understand their counterpart's needs, confront them on issues, and to defend their own positions. As an SSU member explained:

They say how they feel and they usually give examples to explain issues. We give the reasons and we give what actions we are taking. (P2.1)

A BU member explained that the increased interactions helped them empathize with the SSU:

I do see the problem for SSU. If they're not being included in the process, then they can't perform their job properly. Can you imagine if they were on a call with the BU CFO and they said, "No problems, everything's kosher, everything's running perfectly," but the CFO's got a long list of all the problems that have come to him directly? The SSU look bad but in reality they have not been given the visibility to do it! (P3.5)

Similarly, SSU members reported that they became more tolerant of the BUs' challenges:

$B U s$ do not want to get complaints from their suppliers about delayed payments. One $B U$ in particular gets heat for that so we have to make sure that doesn't happen. (P2.1) 
Several BU and SSU members explained that an important consequence of "coming together" was the easing of perceived "process boundaries". They acknowledged that collectively they would perform better if they integrated individual tasks and shared knowledge to develop new ideas. In the new collaborative environment, the BUs also felt that the SSU was ready to go beyond its formal obligations and work closely with the BU members to gain relevant business knowledge.

Rather than just taking its narrow operational scope - working faster, harder, cheaper the SSU actually had to collaborate with what's before and after them in the process. They're really making a difference now and it creates opportunity. The fences have gone down. It means that they now frequently cross borders and understand more about what happens in the other parts of the organization. (P2.6)

Table 6: Interactive behaviors and impact on tensions

\begin{tabular}{|c|c|c|}
\hline SSU Interactive Behaviors & BU Interactive Behaviors & Tensions \\
\hline $\begin{array}{l}\text { Worked to develop } \\
\text { knowledge of BU operations } \\
\text { Attended management } \\
\text { meetings with the BUs } \\
\text { Empathized with BUs }\end{array}$ & $\begin{array}{l}\text { Focused on less } \\
\text { confrontational and informal } \\
\text { indicators of performance } \\
\text { Attended management } \\
\text { meetings with the SSU } \\
\text { Empathized with SSU teams }\end{array}$ & $\begin{array}{c}\text { Accommodated } \\
\text { Tensions were acknowledged } \\
\text { and accommodated as both } \\
\text { sides related better to each } \\
\text { other's needs }\end{array}$ \\
\hline
\end{tabular}

\section{Collaborative behaviors}

SSU members started to take a more collaborative view of their responsibilities and reflect on how their own actions impacted the larger organization. They spoke about picking their battles carefully and explained that they had become better aligned with the BUs' need for flexibility. As they increased their interactions, the focus on imposing rigid controls diminished significantly. One SSU member gave an example of a new online invoicing tool designed to require less manual input from the SSU when collecting payments. The idea was to speed up invoice processing times so that BUs received their customer payments quicker to improve cash flow. The implementation of the tool required the BUs to align their own systems and encourage their customers to adopt the online method of payment. The SSU's business plan aimed for $80 \%$ of invoices to be processed 
through the new invoice system. However, SSU members understood and empathized with the problems the BUs faced in adopting the tool. For instance, not all customers were able to access online payment systems. SSU members discussed the problems with their BU counterparts and agreed to aim for a more realistic $70 \%$, which would allow for the local adaptations required by BUs to accommodate customers.

When you have exceptions, escalations or urgent issues we can now work with SSU members to see how we can overcome them and what our options are. It is a much smoother process. Of course, the SSU has to comply with policy - so in the BUs we try to operate as much as possible within standard processes. But in emergencies we have some temporary flexibility. (P3.8)

BU members also engaged in more collaborative behaviors. They referred to an internal "change in attitude" and began to encourage their SSU counterparts to make their own decisions and propose "improvement projects".

In the past they were treated as subordinates. I think they just kept their heads down because they were so scared of getting things wrong. No one raised any issues, and no one ever came to me in case they'd have their heads bitten off. They now feel empowered to look for things. They'll talk to me and they'll suggest something. Nine times out of ten I'll say "What a brilliant idea. Let's do it". (P3.4)

SSU members noted that the BUs were more welcoming of new initiatives and were proactively approaching the SSU with ideas for improving their collaboration. SSU members explained they felt energized and put in more effort to share knowledge, ideas, and implement new IT tools. For instance, an SSU member who managed the 'purchase-to-pay' area, implemented a set of global KPIs to align and reconcile the goals, objectives and expectations of the BUs, the SSU and the third-party provider:

With the global KPIs there has been a shift from a pure processing focus (how many invoices have we processed?) to a real end-to-end view. Now, everybody needs to understand the tools [e.g. TradeShift and Basware]. In the SSU we need to see end-to-end if there are any issues and where they are coming from. This means going over the borders of our own unit, to the BU, and even towards procurement. (P2.4)

Several BU and SSU members explained that while the integration process had been challenging, it had led them to engage in more collaborative decision-making. The "psychological divide" between the SSU and the BUs had reduced, and the decision-making process had become faster. The SSU stopped complaining about the BUs' systematic resistance to change, and the BUs 23 
stopped opposing SSU initiatives. The confrontational approach was replaced by collaborative discussions and negotiations. The SSU continued to be responsible for cost reduction and process standardization. The BUs continued to be "customer-centric" in their financial decisions but worked collaboratively with the SSU. The BUs acknowledged that the SSU's work on cost reductions and process efficiencies was enabling them (the BUs) to focus squarely on improving their customers' experience.

In the past a lot of the project change capacity was all focused on driving down cost. Now that capability is there for the BUs, but the CFO can easily say "Hey guys, let's park the cost project or the standardization in Asia for a little bit, and focus on this commercial one that has a revenue and customer satisfaction impact". This is now possible! In the past there would be reiterations and reiterations on the SLA impact and the budget. All that stuff has gone. (P2.6)

While formal objectives did not change, the BU and SSU developed new ways of coping with tensions and working with one-another to find collaborative solutions. In accommodating one another, both BU and SSU members made practical trade-offs. For example, the SSU decided to reduce focus on cost reduction projects and increase focus on customer experience projects. Similarly, the BUs volunteered to improve compliance with formal SSU processes. Both sides realized that not sharing knowledge was detrimental to achieving smooth distributed processes. Rather than prioritizing their own objectives, they worked on understanding one-another's tasks as important components of a bigger picture. BUs empowered the SSU to make decisions in the larger interest of the organization even when such decisions made their own (BUs) work temporarily more challenging. SSU members engaged with BU members actively in the decisionmaking process. Overall, both sides explained that process performance had improved in terms of both efficiency (cost and speed) and quality (accuracy and customer service).

Table 7: Collaborative behaviors and impact on tensions

\begin{tabular}{|c|c|c|}
\hline SSU Collaborative Behaviors & $\begin{array}{c}\text { BU Collaborative } \\
\text { Behaviors }\end{array}$ & Tensions \\
\hline
\end{tabular}




\begin{tabular}{|c|c|c|}
\hline $\begin{array}{l}\text { Reduced their demands for } \\
\text { standardization }\end{array}$ & Empowered SSU to & \\
\hline Supported the creation of flexibility & 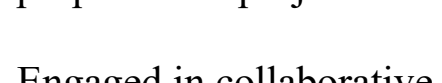 & Tensions were less \\
\hline $\begin{array}{l}\text { Shared knowledge and ideas to } \\
\text { support BUs }\end{array}$ & $\begin{array}{l}\text { Engaged in collaborative } \\
\text { decision-making }\end{array}$ & \\
\hline $\begin{array}{l}\text { Engaged in collaborative decision- } \\
\text { making }\end{array}$ & $\begin{array}{l}\text { Relinquished control of } \\
\text { some processes }\end{array}$ & $\begin{array}{l}\text { them. They worked to } \\
\text { align goals and bridge } \\
\text { misunderstanding. }\end{array}$ \\
\hline
\end{tabular}

\section{Discussion}

The analysis above illustrates several inherent paradoxes in GDW. In particular, it shows how onshore-offshore collaborations involve opposing values and objectives and intense competition for resources and decision-making power. This analysis builds on extant literature which has identified three prominent sources of tensions in GDW - knowledge asymmetries (Oshri et al., 2008; Hahl et al., 2016), power asymmetries (Levina and Vaast, 2008; Ravishankar et al., 2013) and identity threats (Petriglieri, 2011; Koppman et al., 2016). In our case, the three tensions were most evident in the relationship between onshore BU units and the offshore SSU unit. While previous studies have acknowledged tensions and the conflict they create as a pertinent issue, thus far there has been very little understanding of how tensions can be turned into opportunities for effective collaborative practices. Further, only scant research has considered the interactions amongst tensions and how they play out in GDW. Drawing on our analysis and guided by ideas from paradox theory (Lewis, 2000; Smith and Lewis, 2011), we offer three contributions to the literature on GDW.

- First, we illuminate how a sequential enactment of formal and informal solutions may help address tensions and generate more effective onshore-offshore collaborative practices in GDW.

In the literature, tensions and their manifestations have been viewed as being either valuedestroying or value-creating. Symptoms of value-destroying tensions in GDW include a lack of 
ability and willingness to share knowledge (Zimmerman and Ravishankar, 2014), poor integration across distributed process (Levina and Vaast, 2008) and growth of 'in' and 'out' groups (Hinds et al., 2014). Symptoms of value-creating tensions include better integrated activities and acceptance and accommodation of ambivalent situations and contradictions (Lewis, 2000; Sundaramurthy and Lewis, 2003; Johansen, 2018). Our findings go beyond viewing tensions in binary terms. They help explain how instability-generating tensions (i.e., value-destruction) in GDW can turn into an energizing catalyst and create opportunities for creativity and innovation (i.e., value-creation). As we elaborate below, in our case formal structural integration that seemingly intensified paradoxical tensions also led the SSU and the BUs to confront paradoxes directly and move towards more effective collaborative practices.

The SSU had adopted defensive behaviors such as 'working to rule', hiding information, and excessively emphasizing the need to follow processes. On the other side, the BUs leveraged their superior power position to resist change, access information directly from the third-party provider and force flexibility. These behaviors widened the relational gulfs, increased knowledge asymmetries and further reinforced the power imbalances and conflicting objectives. As prior research has shown, such defensive behaviors are frequently used to mute or disguise tensions and avoid 'paralyzing' conflict (Lewis, 2000; Ravishankar et al., 2013). They also ignore the practical effort required to make collaborations work, and can therefore lead to diminished opportunities for better understanding the GDW partner (Levina and Vaast, 2008). Interestingly, the structural separation of the SSU and the BUs - with the SSUs reporting to the GBS and the BUs reporting to the business divisions (see Figure 1) - and the systems used to make this uncoupling work, further exacerbated the paradoxical tensions. As our analysis shows, the two sides were unwilling to cooperate outside of formal obligations and share knowledge with one another and were prone to fiercely protecting their own positions. We would therefore suggest that simple formal solutions (e.g., structural separation of units) may not resolve the paradoxical tensions inherent in GDW. They can be too formulaic to tackle the inherent paradoxes and additionally, may fail to recognize opportunities to generate new collaborative practices from the paradoxical tensions. Equally, as the literature points out, standalone informal coping strategies such as arriving at blatantly stereotypical 'cultural' understandings of the GDW partner's actions may not resolve tensions either. They may in fact hinder collaboration and create bigger relational challenges in the long run (Ravishankar, 2015). 
However, our case suggests that when actors are given the chance to confront paradoxical tensions directly through a careful sequential enactment of both formal and informal solutions, it is conceivable that this will help address tensions and develop more effective collaborative practices. As our analysis shows, structural integration of the SSU and BUs - a formal solution created proximity and forced both sides to share time and space, triggering a series of informal positive interactive behaviors such as frank discussions, empathy for offshore (onshore) counterparts, and demonstrations of better awareness of the paradoxical roots of their collaborative activities. In other words, both sides identified and negotiated relational challenges, and sought to address knowledge and power imbalances and align objectives. While these interactions were often described as uncomfortable, they energized both sides to develop new collaborative ways of working. For instance, our informants explained how 'new' joint meetings and frank discussions improved the speed of decision-making, led to greater knowledge sharing and empowered them to generate new IT tools for 'process improvement'. The key turning point for the emergence of collaborative behaviors was the actions taken by senior managers (i.e. BU CFOs) in overseeing the structural integration of the BUs and $\mathrm{SSU}^{2}$. The integration retained the physical separation of the SSU and BUs but eliminated the structural separation. BU CFOs paid close attention to reducing the power and identity tensions, explaining to the SSU members that they were highly valued, and that the integration was an opportunity to work with the BUs as same-status partners. Thus, they provided both sides (esp. the SSU) a sense of psychological security to approach the integration with positive hope, rather than with worry and fear. This line of thought complements arguments in paradox theory which suggest that squarely facing up to opposing elements, albeit informally, within a safe and formally constructed space, helps mitigate tensions through better awareness and appreciation of mutual positions (Smith and Lewis, 2011; Smith, 2014). In this sense, confronting instead of avoiding may help turn potentially value-destroying tensions into opportunities for value creation (Johansen, 2018). There is a key insight here for the management of distributed teams, which often relies on distance to temper relationships and maintain stability: With an optimal combination of formal and informal solutions, tensions can be managed to improve relationships and encourage collaborate practices in GDW.

\footnotetext{
${ }^{2}$ We thank anonymous Reviewer 2 for this insight.
} 
- Second, based on our analysis we have developed a phasal model which helps explain the evolution and management of tensions in GDW.

Figure 2: Phasal model of tensions in GDW

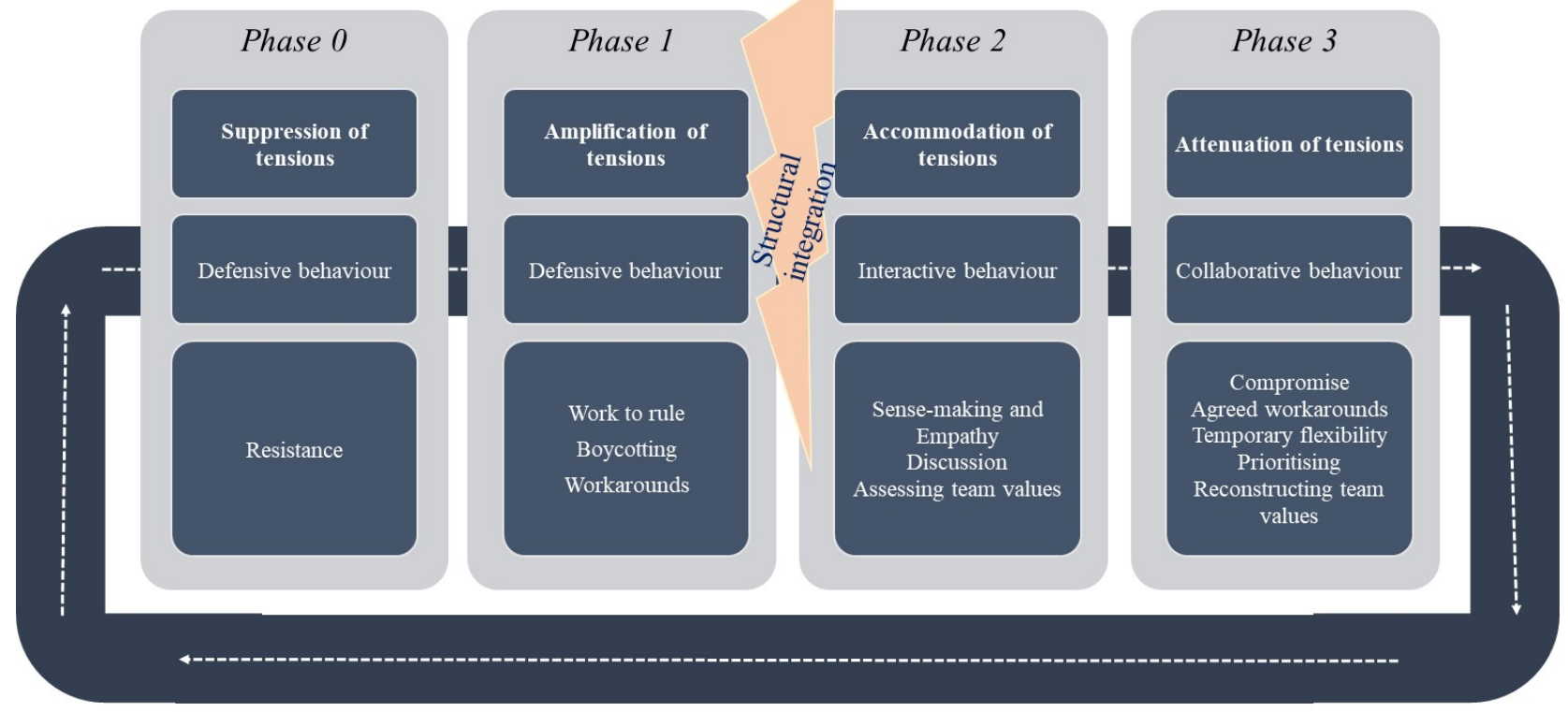

Tensions evolve with onshore-offshore exchanges. Specifically, our empirical data shows how tensions are suppressed, amplified, accommodated and attenuated in globally distributed collaborations (see Figure 2). Tensions evoke defensive behaviors and evolve in response to the behaviors. For instance, SSU's enforcement of formal communication channels compelled BUs to find alternative flexible ways to access information, thus further amplifying tensions. The structural integration of the SSU into the business division meant that both sides had to squarely face the tensions and negotiate differences. The SSU and BUs moved from defensive behaviors, which suppressed and then amplified tensions, to more positive interactive behaviors through which they learned (at least temporarily) to 'live with' and accommodate tensions (Smith and Lewis, 2011). As explained earlier, this process of coming together enabled both sides to better understand the other's perspectives and empathize with the other's motives. Informal meetings led to workarounds, compromises and collaborative behaviors, thereby attenuating tensions.

Our data also suggests that given the inherent and entrenched nature of the paradoxical elements, any resolution or attenuation of tensions may only be temporary. Our informants noted that as situations changed, for example when new activities migrated to the SSU or new members joined the team, tensions re-emerged, requiring further renegotiation in search of an amicable 
solution. As both sides recognized the importance of dedicating time for honest and regular communication over thorny issues, monthly service performance review meetings and regular health checks were established. Thus, building on our phasal model, we suggest that at the heart of managing inherent tensions in GDW is the ongoing negotiation of amicable and 'best fit' solutions at that time.

- Third, we extend prior research by empirically illustrating the interactions of tensions.

Our analysis brought to light interactions amongst knowledge, power and identity tensions, which have been largely implicit in current debate. Only a small set of studies have hinted at interactions of knowledge-power-identity tensions in GDW. For instance, Hahl et al. (2016) imply such interactions in their study of knowledge asymmetries between teams and brokers when they highlight the 'esteem' of those brokering as an important influence on teams' willingness to share knowledge and reduce asymmetries. Similarly, Levina and Vaast (2008) refer to the status of teams as an important facet of knowledge sharing and innovation in GDW, while Zimmermann and Ravishankar (2011) argue that asymmetrical status positions influence the professional role identities of offshore-onshore units. Overall however, interactions between knowledge, power, and identity tensions have not been explicitly considered or illustrated in prior GDW research. Our analyses point to such interactions and their importance for effective collaboration.

\section{Defensive behaviors and interaction of tensions}

In the suppression-amplification phases (see Figure 2), the SSU tried to strengthen its weaker power-identity position in the relationship (being perceived as a 'transactional' 'poorer cousin' with limited access to decision makers, less investment and limited authority to enforce process changes) by asserting its stronger knowledge position and insisting that the BUs use formal systems for information exchanges. Such an emphasis on its knowledge position amplified the knowledge tensions between the two sides (Table 5). Thus, we would suggest that against a background of defensive behaviors efforts to reduce power and identity tensions in GDW can further aggravate knowledge tensions.

In turn, BUs attempted to maintain their stronger power-identity position and distract attention away from their weaker knowledge position. They emphasized their status as profit centers and their 'customer' proximity to ignore SSU mandates about the use of formal systems: The decision 
power should always lie with us in the BU. Transactional work or data gathering can be with them (P3.9). This behavior not only created further knowledge tensions by hiding important business information from the SSU team, but also reinforced the power and identity tensions. Extrapolating from these observations, we would suggest that against a background of defensive behaviors efforts to maintain power and identity tensions in GDW can exacerbate knowledge tensions and worsen power and identity tensions.

\section{Interactive-collaborative behaviors and interaction of tensions}

The accommodation-attenuation phases (see Figure 2) involved a transition to interactive and collaborative behaviors. As the analysis shows, BUs empowered their SSU counterparts and in return, the SSU reduced knowledge tensions by better integrating distributed knowledge and by sharing their 'process' knowledge. Thus, we would suggest that against a background of interactive-collaborative behaviors efforts to reduce power tensions in GDW can help reduce knowledge tensions. Several informants noted this improvement in the knowledge tension situation: The fences have gone down. It means that they now frequently cross borders and understand more about what happens in the other parts of the organization. (P2.6).

The SSU also worked to improve their power position by offering more 'valued' services, which opened access to decision makers and financial resources. The SSU also started sharing knowledge with the BUs: ...there has been a shift from a pure processing focus (how many invoices have we processed?) to a real end-to-end view (P2.4). The attenuation of power and knowledge tensions not only removed the hostility between teams, but (as described in the case analysis) but also had a positive impact on reducing identity tensions (e.g., the 'us' and 'them' barriers). Thus, we would suggest that against a background of interactive-collaborative behaviors efforts to reduce power and knowledge tensions in GDW can help reduce identity tensions. From a theoretical standpoint, these preliminary insights about how addressing one tension can potentially impact others calls for a greater focus on interactions amongst multiple tensions in distributed working environments. From a practical standpoint, it calls for more comprehensive and sophisticated strategies to manage tensions in GDW.

\section{Implications for paradox research and GDW practice}


Thus far, studies of paradox have focused on a central actor who is challenged with accommodating two competing ideas (Lewis, 2000; Smith, 2014), such as novelty and usability (Miron-Spektor and Erez, 2017), innovation and efficiency (Andriopoulos and Lewis, 2009), and competition and cooperation (Rai, 2016). In all these cases, the actor is positioned as the focal point, facing two opposing forces. As a point of departure, here we have elaborated on how one side of the paradox (BUs) is at odds with the other side (the SSU). This viewpoint extends the somewhat traditional focus in the paradox literature on one central actor (or group) who can comprehend each opposing element individually, to include actors (e.g., onshore-offshore units) that are often unfamiliar with the specifics of one-another's tasks, objectives, and values. Our analysis suggests that while formal strategies create a common lexicon and standardized rules for performing different parts of the distributed process, the inherently contradictory elements of the two GDW sides and the added complexity of distance mean that knowledge, power and identity tensions are harder to overcome. Our case suggests that organizations may need to take additional steps (e.g., structural realignments) to ensure that actors comprehend the inherently contradictory elements before attempting to engage in meaningful collaborative practices. Managers need to be sensitive, first and foremost, to the perceived power and identity tensions, which may amplify with the implementation of structural changes. They need to address the source of these tensions, by giving all sides the reassurance and confidence that their interests will be protected and by explaining the honest efforts being made to generate strategic value through the collaboration. The empirical material suggests that once individuals become better aware of, and empathize with, each other's positions, the perception of power asymmetries and identity threats are likely to subside. In such a relatively benign environment, as we saw in our data, conflicting teams are likely to take concrete measures on their own to reduce knowledge tensions.

The structural integration meant that the business division's CFO became responsible for the BU and SSU teams and in many respects acted as the arbitrator. The success of this simplified hierarchical arrangement has two implications for practice. First, it indicates that even when teams are physically separate, having a common leader can help mitigate tensions. Second, it suggests that it may be crucial for such a leader, in the aftermath of the structural integration, to engage with the conflicting sides on a 'human' and 'informal' level rather than escalate the dependence on formal IT tools and systems. It is possible that many managers leading GDW relationship rely on formal IT tools to ease coordination and communication challenges, and to minimize or 
overcome conflict. They may find this paper useful for designing or re-designing their management of distributed teams. Our study suggests that over-reliance on formal IT tools (e.g., the creation of a common lexicon and standardized processes) can be counterproductive. Instead, our findings suggest that organizations need to create opportunities for GDW teams to informally discuss, challenge, and negotiate power, knowledge and identity tensions in an open and transparent manner. One way in which organizations can support this may be to invest in platforms (online or offline) which offer GDW partners a safe space to engage in informal, and potentially constructive, meetings. However, a big challenge organizations face (and one that is admittedly not fully explored in this study) is understanding whether defensive behaviors stem from attempts to overcome inadequacies in the work system, or whether they are driven by the self-interest of actors taking short-cuts, resisting change and protecting their jobs. If it is mostly the former, then the challenge for managers is to balance the inherent paradoxes in a stable and coherent work system that fosters constructive GDW partnerships. If it is the latter, managers need to re-empower teams by better communicating the value of new (or evolving roles) and helping actors develop positive evaluations of their professional selves.

\section{Limitations and future research}

The arguments in this paper are based on a single in-depth case study. While this approach is consistent with the underlying principles and aims of qualitative research, care must be taken in transferring insights to other contexts. Another limitation of our study is that the data for phases 0 and 1 (Figure 2) was captured retrospectively. We encourage scholars to adopt longitudinal methods to capture timely accounts of how multiple tensions evolve as GDW units collaborate over time. The collaborative behaviors we saw from both sides led to what some participants described as 'small wins'. There was a better handling of trade-offs as both sides began working with each other. However, we acknowledge that managing trade-offs is not the ultimate objective here. Collaborative behaviors and better appreciation of mutual positions lay a solid foundation for genuine value creation through the offshore (SSU) - onshore (BUs) relationship. More research is needed to explicate the process of generating strategic value through collaborative behaviors in paradoxical GDW relationships. Our case focuses on inherent contradictions in the relationship between onshore BUs and an offshore SSU. However, it is likely that the corresponding tensions 
could play out differently in different outsourcing and offshoring arrangements. Further research is needed to explore such variations. More work is also needed to understand how collaborative practices emerge as outsourcing/offshoring arrangements become more complex with the application of automation and artificial intelligence technologies.

We have shown how even when they cannot entirely resolve the inherent contradictions in GDW, a sequence of formal and informal solutions can address the corresponding tensions and improve collaborative practices. However, it is possible that in some cases, a sequence of similar formal and informal solutions may worsen rather than improve opportunities for collaboration. Future research needs to closely investigate the range of conditions in GDW that invariably lead to negative manifestations of tensions and poor relationships. Our case featured a relationship between onshore BUs and an offshore SSU. However, we have not investigated in detail the extent to which geographic distance influenced the tensions. Indeed, some of the tensions may also appear

in co-located and proximally located teams although distance obviously introduces a new dimension to the relationship. More research is needed to compare and contrast the influence of a wide array of possible geographic distances from onshore units (e.g., offshore - in the same continent; offshore - in a different continent) on the evolution of tensions in GDW. Finally, given that empirical research on paradox has so far largely restricted itself to contexts of equal power relations, there is a need for a more explicit focus on management of paradoxes in settings riddled with significant power asymmetries (Hargrave and Van de Ven, 2017; Smith et al., 2017).

\section{Concluding remarks}

In this paper, we have drawn on paradox theory in considering the intrinsic and entrenched nature of knowledge, power and identity tensions in GDW. While it may be hard to completely and conclusively reconcile the paradoxical elements underpinning GDW tensions, our study suggests that a sequential enactment of formal and informal solutions can help situated actors move towards better collaborative working practices with their GDW counterparts. Tensions in GDW evolve in phases and require a careful ongoing negotiation between diverse groups of stakeholders. Crucially, improvements in collaborative practices cannot be taken for granted since new demands, on say, an offshore unit may trigger new interactions amongst tensions and significantly harm the offshore unit's relationship with its corresponding onshore unit. Thus, effective management of 
paradox is a difficult and often fragile achievement in GDW settings. Given the increasing proliferation of GDW projects and initiatives, we would encourage scholars to build on our study and look closely into how specific interactions between tensions may be exploited to generate value for organizations engaged in GDW.

\section{References}

Andriopoulos, C. and Lewis, M.W. (2009). Exploitation-Exploration Tensions and Organizational Ambidexterity: Managing Paradoxes of Innovation Organization Science 20(4): 696-717.

Barney, S., Mohankumar, V., Chatzipetrou, P., Aurum, A., Wohlin, C. and Angelis, L. (2014). Software quality across borders: Three case studies on company internal alignment, Information and Software Technology 56(1): 20-38.

Bengtsson, M. and Kock, S. (2000). "Coopetition" in business networks - To cooperate and compete simultaneously, Industrial Marketing Management 29(5): 411-426.

Bengtsson, M., Raza-Ullah, T. and Vanyushyn, V. (2016). The coopetition paradox and tension: The moderating role of coopetition capability, Industrial Marketing Management 53: 1930.

Cha, H.S., Pingry, D.E. and Thatcher, M.E. (2008). Managing the knowledge supply chain: An organizational learning model of information technology offshore outsourcing, MIS Quarterly 32(2): 281-306.

Chen, Y., Bharadwaj, A. and Goh, K.-Y. (2017). An Empirical Analysis of Intellectual Property Rights Sharing in Software Development Outsourcing, MIS Quarterly 41(1): 131-161.

Connelly, C.E., Zweig, D., Webster, J. and Trougakos, J.P. (2011). Knowledge hiding in organizations, Journal of Organizational Behavior 33(1): 64-88.

Corley, K. and Gioia, D. (2004). Identity Ambiguity and Change in the Wake of a Corporate Spinoff, Administrative Science Quarterly 49(2): 173-208.

Cousins, K. C., Robey, D. and Zigurs, L. (2007). Managing strategic contradictions in hybrid teams, European Journal of Information Systems, 16(4): 460-478.

David, G. C., Chand, D., Newell, S. and Resende-Santos, J. (2008). Integrated collaboration across distributed sites: The perils of process and the promise of practice, Journal of Information Technology 23(1): 44-54.

Deloitte (2016). Global Business Services: Performance Improvement, https://www2.deloitte.com/content/dam/Deloitte/us/Documents/process-andoperations/us-operations-global-business-services.pdf 
Di Tullio, D. and Staples, D. (2013). The Governance and Control of Open Source Software Projects, Journal of Management Information Systems 30(3): 49-80.

Dibbern, J., Winkler, J. and Heinzl, A. (2008). Explaining variations in client extra costs between software projects offshored to India, MIS Quarterly 32(2): 333-366.

Druskat, V. U. and Wheeler, J. V. (2003). Managing from the Boundary: The Effective Leadership of Self-Managing Work Teams, Academy of Management Journal, 46(4): 435-457.

Dubé, L. and Robey, D. (2009). Surviving the paradoxes of virtual teamwork, Information Systems Journal, 19(1): 3-30.

Eisenberg, J. and Mattarelli, E. (2016). Building Bridges in Global Virtual Teams: The Role of Multicultural Brokers in Overcoming the Negative Effects of Identity Threats on Knowledge Sharing Across Subgroups, Journal of International Management 23(4): 399411.

Eisenhardt, K.M. (1989). Building Theories from Case Study Research, Academy of Management Review 14(4): 532-550.

Goo, J., Nam, K. and Kishore, R. (2009). The Role of Service Level Agreements in Relational Management of Information Technology Outsourcing: An Empirical Study, MIS Quarterly 33(1): 119-145.

Hahl, O., Kacperczyk, A. and Davis, J. P. (2016). Knowledge asymmetry and brokerage: Linking network perception to position in structural holes, Strategic Organization 14(2): 118-143.

Hargrave, T.J. and Van de Ven, A.H. (2017). Integrating Dialectical and Paradox Perspectives on Managing Contradictions in Organizations, Organization Studies 38(3-4): 319-339.

Hinds, P.J. and Mortensen, M. (2005). Understanding Conflict in Geographically Distributed Teams: The Moderating Effects of Shared Identity, Shared Context, and Spontaneous Communication, Organization Science 16(3): 290-307.

Hinds, P.J., Neeley, T.B. and Cramton, C.D. (2014). Language as a lightning rod: Power contests, emotion regulation, and subgroup dynamics in global teams, Journal of International Business Studies 45(5): 536-561.

Jarvenpaa, S.L. and Majchrzak, A. (2016). Interactive self-regulatory theory for sharing and protecting in interorganizational collaborations, Academy of Management Review 41(1): $9-27$.

Jarzabkowski, P., Lê, J. K. and Van de Ven, A. H. (2013). Responding to competing strategic demands: How organizing, belonging, and performing paradoxes coevolve, Strategic Organization, 11(3): 245-280.

Jarzabkowski, P. A. and Lê, J. K. (2017). We have to do this and that? You Must be Joking: Constructing and Responding to Paradox Through Humor, Organization Studies, 38(3-4): 
433-462.Johansen, J.H. (2018). Paradox Management: Contradictions and Tensions in Complex Organizations, London, UK: Palgrave Pivot.

Koppman, S., Mattarelli, E. and Gupta, A. (2016). Third-World "Sloggers" or Elite Global Professionals? Using Organizational Toolkits to Redefine Work Identity in Information Technology Offshore Outsourcing, Organization Science 27(4): 825-845.

Kotlarsky, J., Scarbrough, H. and Oshri, I. (2014). Coordinating Expertise Across Knowledge Boundaries in Offshore-Outsourcing Projects: The Role of Codification, MIS Quarterly 38(2): 607-627.

Kotlarsky, J., Rivard, S., Oshri, I. (2016). On a Supplier's Paradoxical Practices: The Case of Technological Innovations in Outsourcing Engagements, Conference Proceedings, Thirty Seventh International Conference on Information Systems, Dublin 2016. https://aisel.aisnet.org/icis2016/ISStrategy/Presentations/2/\#.XQPHRJNNPcU

Leonardi, P.M. and Bailey, D.E. (2008). Transformational technologies and the creation of new work practices: Making implicit knowledge explicit in task-based offshoring, MIS Quarterly 32(2): 411-436.

Leonardi, P.M. and Bailey, D.E. (2013). Recognizing and Selling Good Ideas: How Brokers Mediate Knowledge Transfer, Academy of Management Proceedings 2013(1):

Leonardi, P.M. and Rodriguez-Lluesma, C. (2013). Occupational Stereotypes, Perceived Status Differences, and Intercultural Communication in Global Organizations, Communication Monographs, 80(4): 478-502.

Levina, N. and Kane, A. (2009). "I am not one of them anymore": Onshore immigrant managers on offshore development projects, Academy of Management Proceedings 2009(1): 1-6.

Levina, N. and Vaast, E. (2008). Innovating or doing as told? Status differences and overlapping boundaries in offshore collaboration, MIS Quarterly 32(2): 307-332.

Lewis, M.W. (2000). Exploring paradox: Toward a more comprehensive guide, Academy of Management Review, 25(4): 760-776.

Mayasandra, R., Pan, S.L., and Myers, M.D. (2006). Viewing information technology outsourcing organizations through a postcolonial lens. In IFIP International Federation for Information Processing, Volume 208, Social Inclusion: Societal and Organizational Implications for Information Systems, eds. Trauth, E., Howcroft, D., Butler, T., Fitzgerald, B., DeGross, J., (Boston: Springer), pp. 381-396.

Miron-Spektor, E. and Beenen, G. (2015). Motivating creativity: The effects of sequential and simultaneous learning and performance achievement goals on product novelty and usefulness, Organizational Behavior and Human Decision Processes 127: 53-65.

Newell, S., David, G. and Chand, D. (2007). An analysis of trust among globally distributed work teams in an organizational setting, Knowledge and Process Management 14(3): 158-168. 
Oshri, I., Van Fenema, P. and Kotlarsky, J. (2008) 'Knowledge transfer in globally distributed teams: The role of transactive memory', Information Systems Journal, 18(6), pp. 593-616.

Oxley, J.E. and Sampson, R.C. (2004). The scope and governance of international R\&D alliances, Strategic Management Journal 25(89): 723-749.

Parker, G., Van Alstyne, M. and Jiang, X. (2017). Platform Ecosystems: How Developers Invert the Firm, MIS Quarterly 41(1): 255-266.

Petriglieri, J.L. (2011). Under threat: Responses to and the consequences of threats to individuals' identities, Academy of Management Review 36(4): 641-662.

Plambeck, N. and Weber, K. (2010). When the glass is half full and half empty: CEOs' ambivalent interpretations of strategic issues, Strategic Management Journal 31: 689-710.

Poole, M.S. and van de Ven, A.H. (1989). Using Paradox to Build Management and Organization Theories, Academy of Management Review 14(4): 562-578.

Rai, R.K. (2016). A Co-opetition-Based Approach to Value Creation in Interfirm Alliances, Journal of Management 42(6): 1663-1699.

Ravishankar, M.N. (2015). The realignment of offshoring frame disputes (OFD): an ethnographic “cultural" analysis, European Journal of Information Systems 24(3): 234-246.

Ravishankar, M.N., Pan, S.L. and Myers, M.D. (2013). Information technology offshoring in India: a postcolonial perspective, European Journal of Information Systems 22(4): 387402.

Schuman, S., Stutz, S., and Ward, J. (2010). Family Business as Paradox. New York: Palgrave.

Smith, W.K. (2014). Dynamic decision making: A model of senior leaders managing strategic paradoxes, Academy of Management Journal 57(6): 1592-1623.

Smith, W.K., Erez, M., Jarvenpaa, S., Lewis, M.W. and Tracey, P. (2017). Adding Complexity to Theories of Paradox, Tensions, and Dualities of Innovation and Change: Introduction to Organization Studies Special Issue on Paradox, Tensions, and Dualities of Innovation and Change, Organization Studies, 38(3-4): 303-317.

Smith, W.K. and Lewis, M.W. (2011). Toward a theory of paradox: A dynamic equilibrium model of organizing, Academy of Management Review 36(2): 381-403.

Stadtler, L. and Van Wassenhove, L.N. (2016). Coopetition as a Paradox: Integrative Approaches in a Multi-Company, Cross-Sector Partnership, Organization Studies 37(5): 655-685.

Sundaramurthy, C. and Lewis, M. (2003). Control and collaboration: Paradoxes of governance, Academy of Management Review 28(3): 397-415/

Tiwana, A. and Keil, M. (2007). Does peripheral knowledge complement control? An empirical test in technology outsourcing alliances, Strategic Management Journal 28(6): 623-634. 
Tzabbar, D. and Vestal, A. (2015). Bridging the Social Chasm in Geographically Distributed R\&D Teams: The Moderating Effects of Relational Strength and Status Asymmetry on the Novelty of Team Innovation, Organization Science 26(3): 811-829.

Vlaar, P.W., Van Fenema, P.C. and Tiwari, V. (2008). Cocreating Understanding and Value in Distributed Work: How Members of Onsite and Offshore Vendor Teams Give, Make, Demand, and Break Sense, MIS Quarterly 32(2): 227-255.

Walsham, G. (2006). Doing interpretive research, European Journal of Information Systems, 15(3): 320-330.

Zimmerman, A. and Ravishankar, M.N. (2011). Collaborative IT offshoring relationships and professional role identities: Reflections from a field study, Journal of Vocational Behavior 78(3): $351-360$.

Zimmermann, A. and Ravishankar, M.N. (2014). Knowledge transfer in IT offshoring relationships: The roles of social capital, efficacy and outcome expectations, Information Systems Journal 24(2): 167-202.

Zimmermann, A. and Ravishankar, M.N. (2016). A systems perspective on offshoring strategy and motivational drivers amongst onshore and offshore employees, Journal of World Business 51(4): 548-567.

Zolin, R., Hinds, P. J., Fruchter, R., and Levit, R. E. (2004). Interpersonal trust in cross-functional, geographically distributed work: a longitudinal study. Information and Organization, 14(1): $1-26$. 


\section{Appendix: Participant roles and data reference codes}

\begin{tabular}{|c|c|c|c|c|}
\hline Round & Participant Job Role & $\begin{array}{l}\text { Interview } \\
\text { length } \\
\text { (hours) }\end{array}$ & Team & $\begin{array}{c}\text { Data } \\
\text { Reference }\end{array}$ \\
\hline 1 & $\begin{array}{l}\text { Transition and Transformation Manager for } \\
\text { Europe }\end{array}$ & $1: 19$ & SSU & P1.1 \\
\hline 1 & Global Process Owner & $1: 31$ & SSU & P1.2 \\
\hline 1 & $\begin{array}{l}\text { General / Site Manager and } \\
\text { Global Process Owner }\end{array}$ & $0: 53$ & SSU & P1.3 \\
\hline 1 & $\begin{array}{l}\text { Process Expert for Europe, the Middle East } \\
\text { and Africa / Control Tower Lead }\end{array}$ & 1:05 & SSU & P1.4 \\
\hline 1 & Head of Transition and Transformation & $1: 12$ & SSU & P1.5 \\
\hline 1 & $\begin{array}{l}\text { Transition and Transformation Project } \\
\text { Manager }\end{array}$ & 1:19 & SSU & P1.6 \\
\hline 1 & Head of Learning and Development & $1: 27$ & SSU & P1.7 \\
\hline 1 & Global Deployment Manager & $0: 53$ & SSU & $\mathrm{P} 1.8$ \\
\hline 1 & Head of BPO & $0: 57$ & SSU & P1.9 \\
\hline 2 & Financial Accounting Manager & $2: 29$ & SSU & P2.1 \\
\hline 2 & $\begin{array}{l}\text { Head of Performance Management Europe \& } \\
\text { Global Coordinator for Performance } \\
\text { Management }\end{array}$ & 1:09 & SSU & $\mathrm{P} 2.2$ \\
\hline 2 & Acting Service Delivery Expert & $1: 18$ & SSU & $\mathrm{P} 2.3$ \\
\hline 2 & Global Process Owner & $0: 48$ & SSU & P2.4 \\
\hline 2 & Global Head of Financial Accounting & $0: 57$ & FO & $\mathrm{P} 2.5$ \\
\hline 2 & VP, HR for Finance & 1:46 & FO & P2.6 \\
\hline 2 & $\begin{array}{l}\text { Communications \& Employee Engagement } \\
\text { Manager }\end{array}$ & $1: 29$ & SSU & P2.7 \\
\hline
\end{tabular}




\begin{tabular}{|c|c|c|c|c|}
\hline 2 & Vice President, Provider Management & $1: 11$ & FO & P2.8 \\
\hline 3 & Chief Financial Officer: Country Level & $0: 52$ & BU & P3.1 \\
\hline 3 & Chief Financial Officer: Country Level & $1: 04$ & BU & P3.2 \\
\hline 3 & Head of Controlling: Country Level & $1: 34$ & $\mathrm{BU}$ & P3.3 \\
\hline 3 & Head of Governance: Country Level & $1: 10$ & $\mathrm{BU}$ & P3.4 \\
\hline 3 & $\begin{array}{l}\text { Risk, Finance, and Reconciliation Controller: } \\
\text { Country Level }\end{array}$ & $1: 03$ & BU & P3.5 \\
\hline 3 & $\begin{array}{l}\text { Risk, Finance, and Reconciliation Controller: } \\
\text { Country Level }\end{array}$ & $1: 11$ & BU & P3.6 \\
\hline 3 & Chief Financial Officer: Country Level & $1: 03$ & BU & P3.7 \\
\hline 3 & Chief Financial Officer: Country Level & $1: 33$ & BU & P3.8 \\
\hline 3 & $\begin{array}{l}\text { Head of Commercial Controlling and OTC: } \\
\text { Country Level }\end{array}$ & 2:00 & $\mathrm{BU}$ & P3.9 \\
\hline
\end{tabular}

